\title{
Analysis of Information Literacy Education Strategies for College Students Majoring in Science and Engineering
}

\author{
Tingting Liu \& Haibin Sun \\ Institute of Physics and Electronic Engineering, Taishan University \\ Tai'an, Shandong, 271021, China \\ E-mail:1ttphd@163.com
}

Received: July 6, 2011

Accepted: August 15, 2011

doi:10.5539/mas.v5n5p227

Item Project: the topic of educational science "11th Five-Year Plan" in Shandong Province(No.: 2010GG402).

\begin{abstract}
Information literacy has become a necessity for everyone; it forms the basis of lifelong learning. Information literacy is highly important for college studen in science and engineering disciplines. Information literacy education is not just in the research field of librarians nowadays. In higher education for science and engineering, information literacy can be integrated across the curriculum. Some effective strategies can be implemented to improve college students' information literacy. While students leave the campus, they have the ability to use information effectively and can easily keep up with new developments of science, technology and engineering.
\end{abstract}

Keywords: Information literacy, Undergraduates of science and engineering, Higher education, Integration

\section{Introduction}

Since Paul Zurkowski, the president of American information industrial association, put forward the concept of information literacy in 1974, information literacy has become one of hot topic in educational circles at home and abroad.

Information literacy is one basic existence skill, which forms the basis of lifelong learning (Abdelaziz Abid, 2008) and the key for people to become independent lifelong learner in information society. Information literacy is mainly shown as follows: ability to apply to information technology tools; ability to obtain information initiatively; ability to review, collect, use, deliver and exchange information; good coordinative awareness and cooperation ability; information immunity and information ethics cultivation; ability to use the information obtained to solve problems and carry out creative thinking activities.

In 2000, American universities and Association of College and Research Libraries, ACRL passed "Information Literacy Competency Standards for American higher education ". (ACRL, 2008). As guideline that teachers evaluate colleges' students' information literacy situations, the production of this information literacy standards had great directive significance on the education of information literacy and was adopted by colleges and universities in many countries and regions successively. In November 2005, United Nations Educational, Scientific and Cultural Organization (UNESCO), International Federation of Library Associations (IFLA) and The National Forum on Information Literacy published "The Alexandria Proclamation" in the city of Alexandria in Egypt. The declaration proclaim that information literacy and lifelong learning are the beacons of the Information Society, illuminating the courses to development, prosperity and freedom. Information literacy enriches all the countries' social connotation and is crucial to the competitive advantage of individuals, enterprises, regions and nations (IFLA, 2008). In 2006, ACRL passed Information literacy standards for science and engineering/ technology. The standards included 5 standards, 24 performance indicators and 104 outcome indictors, which were used to evaluate students' information literacy education majoring in science, engineering and technology at each level in higher education and aimed to cultivate students' information literacy ability in the field of science and technology (ACRL, 2008).

The rapid development of mehtods and abilities of mass media in information sciety make students not only obtain various information on campus (classroom, libery, laboratory), but also rapied increase methods and amount that obtain information outside school(society, household). Information literacy can not only help college students effectively identify, evaluate, review and use information from diversified information resources in their learning process, but also make colleges students adapt to daily life with good independency and 
effectiveness. After they leave school, good information literacy can help them become high-efficiency and powerful knowledge workers, well-informed customers and lifeful citizens, who are proficient in their own fields and can make wise choices according to their needs(I.A. Mokhtar, S. Majid, 2006).

Such majors as science and engineering are closely related to information technology and they drive and promotes each other. So the majors such as science and engineering proposed higher requirements aabouth the inditification, evaluation, acquiry and usage of information, which are different from other displines obviously. Similarly, for scientists doing experiments and engineers who major in science and engineering, to know how to keep in step with their own developmental direction closely and grasp the sources of new experiments data and research data becomes more important. Information literacy have very important role for students majoring in science and engineering, because they can touch various information resources in the process of learning professional knowledge(Abdelaziz Abid, 2008).

\section{Information literacy education strategies for college students majoring in science and engineering}

Information literacy education for college students majoring in science and engineering should not only be limited to the learning of the course of Computer Cultural Basis, but implement information literacy education directively in specialty curriculum teaching, in order to promopt the improvement of college students' information literacy.

\subsection{Guided by constructivism, realize the integration of information technology with specialty curriculum and promote students' knowledge construction}

The education viewpoint of constructivism pointed out: teaching is centered on students, and students are the subjects of information processing and those who take the initiative to construct significance, rather than passive recipients of external stimuli. Students positively construct knowledge based on existing concepts; teachers are the helpers and promoters of knowledge significance construction, and the organizers and instructors of classroom teaching; Ideal learning environment includes context, collaboration, conversation and meaning constructing, which means that students acquire knowledge using necessary information, depending on other people's (teachers, partners, parents, society) guide, help, collaboration and communication, under certain circumstances (social and cultural backgrounds).

Guided by the theory of constructivism, to realize the organic integration of information technology with specialty curriculum is one of effective paths to develop the information literacy of students majoring in science and engineering. Taking the contents of information literacy education into talents training planning, course syllabus and practical teaching is beneficial to practice information literacy education comprehensively. The essence of the integration between information technology and specialty curriculum is combining the subjects characteristics and applying modern information technology to gradually realize the reform such as the way to present teaching contents, f students' learning method, teachers' teaching methods and teachers' interaction method with students, fully bring the role of information technology into play and provide good learning environment and powerful learning tools for students' learning and development(Wang Fei. 2006).

Therefore, higher education in science and engineering based on the theory of constructivism not only passes on professional knowledge to undergraduates, but provides learning backgrounds with individual and social meaning for undergraduates. The key to integrate information technology with specialty curriculum is to cultivate that undergraduates learn to take information technology as a cognitive tool to obtain information, explore problems, solve problems and construct knowledge. When teachers carry on the teaching design, they take constructivism as guideline, fully consider various characteristics of information technology, definite that is centered on students, emphasize on the construction of learning context and environment as well as learners' exploration and collaboration, fully make use of various information resources to enrich teaching contents.

\subsection{Make use of information technology to create visional learning context, promote the acquisition of knowledge}

The application of information technology provides good education environment and powerful learning tools for undergraduates' professional learning and development. Information technology may help undergraduates present and verify the information from their brain in information technology tools, and inspire their thinking and broaden their thoughts, making them learn and develop through positive and initiative observation, analysis and exploration.

Higher education in science and engineering should, based on nature and life, makes full use of various information technology methods (film, video tape, lantern slides, projection, media-computer, classroom network, school network, Internet, artificial intelligence technology, communication technologies), gives play to 
the optimal combination effects and creates a series of learning context, which makes undergraduates positively participate in and experience to enrich the appearance of learning and finish the significance construction of professional knowledge through observation, experiment, problem exploration and information communication in the perceptual context their teachers create.

In the teaching of professional knowledge, teachers may organize activities such as writing of technological thesis, technology competition, technological website competition, technological blackboard newspaper competition, which can cultivate students' sensitive information awareness, the ability to apply to information technology tools, the ability to positively obtain information, the ability to retrieve, select, identify, use, express and output information, and on the basis students' innovation ability is cultivated. For example, in the process of teaching theoretical mechanics, if students are requested to simulate classical problems of theoretical mechanics, for example, the scattering of a particle, eastward deflection of a free falling body, conning gyratory motion, such scientific computation software as Maple, Matlab, Mathematica, Mathcad, this not only increases the information capacity of classroom teaching, making abstract physical context and process visualized, conductive to highlight the stress points and overcome difficult points and thus promote students' command of knowledge, but also make students learn the application of common scientific computation software and promote the improvement of learning method (Sun Haibin, 2007).

\subsection{Make full use of quality teaching resources based on internet, promote the conversation of learning method}

The classroom teaching supported by modern information technology cannot adapt dependent on former learning method. Students' learning method must make necessary adjustment including: individual learning, cooperative learning, inquiry learning, game learning, situated learning.

Network is an is an important part of modern information technology. In the process of teaching professional knowledge, teachers can develop undergraduates' information literacy through internet-based teaching. The quality curriculum based on internet can provide multiple digital learning resources for undergraduates, create directive virtual classroom, provide interactive learning environment with rich figures, direct images and friendly interface and round-the clock, all-round open learning resources. Teachers may communicate with undergraduates remotely through internet (Email, BBS, chat room, online demo and answer) and guide students to study independently according to their own characteristics. Digital quality curriculum resources may enrich and broaden the horizons of classroom teaching in science and engineering, which makes undergraduates understand technological development status rapidly and is conductive to expand students' professional knowledge and perfect knowledge structure.

As one teaching mode, internet-based quality curriculum also may promote undergraduates in science and engineering to positively carry out professional knowledge based on network. In students' independent learning, teachers positively guide students to understand and master main characteristics and strategy of different information technology, lead students to learn to analyze and understand learning targets, and automatically search information resources related to learning targets through reasonably choosing retrieval method, skills and strategy. Undergraduates make study plan according to learning targets and then make use various media to adopt effective path and learning strategy to learning. Meanwhile, they communicate with teachers and classmates in time through internet and explore various problems they encounter in depth. Through such thinking methods as analysis, comparison, conclusion and abstract, they form the concepts and laws, finish learning task and promote the construction of individual knowledge structure.

Teachers should pay more attention to guiding undergraduates to think how to apply to their professional knowledge and upload their own various learning achievements (for example, essay, DIY, courseware, website) online in order to interact with their teachers and classmates. Independent learning based on internet promotes undergraduates' majoring in science and technology master in their professional knowledge and cultivate their abilities of computer and network application as well as the awareness of cooperating with others and abilities to deal with information.

\subsection{Set up literacy retrieval courses combined with specialized courses teaching and develop undergraduates' information ability}

Set up literacy retrieval courses combined with specialized courses teaching expands the teaching content of literacy retrieval courses greatly and enrich teaching methods. Under the premise of emphasis on information technology, course contents can closely relate to professional knowledge and strengthen the path, method and strategy to obtain literacy information resources using internet (Yao, Shiyan, 2010). In the process of teaching, the education of information theory and information retrieval skill is carried out, and according to the characteristics of curriculum of science and engineering, several main databases (for example, cnki, superstar 
digital library, Wanfang data, SCI, EI, ISTP, EBSCO, IOPP, ScienceDirect, SpringerLink, IEEE Xplore for majors in science and engineering), the skill and knowledge about online retrieval and network information retrieval are explained. Such contents as information awareness, information morality and information ethics are paid more attention to running through total teaching activities and thus realize organic integration of network technology and professional courses (Yao, Shiyan, 2010).

This kind of infiltration education of information literacy can make students grasp fundamental theory of literature information retrieval and basic technology of information retrieval, know literature information resources related to their majors well and consolidate their professional knowledge.

\subsection{Comprehensively develop undergraduates' information ability through research projects}

Research projects are effective ways for undergraduates in science and engineering to carry out information literacy education. Undergraduates' research projects may be blended in each link of daily teaching, for example, classroom teaching, after-class tutoring, experimental teaching, practice et al. The research projects of undergraduates in science and engineering should pay attention to the participation in the process, practice and innovation as well as feasibility (Yan, Maohua \& Lu, Changmei, 2008). The research projects that are suitable for undergraduates in science and engineering mainly include: sub-project of teachers' research projects, social practical and investigative research projects based on social and economic development; undergraduates' innovative project of science and technique; project of open laboratory; Selected topic of graduation design and graduation thesis.

The directive role of teachers should be played fully in the process of research projects. Teachers can guide and lead their students in the aspects including research method, technological method, solution to design of experiment, literature retrieval, writing of research report. Through participating in research projects, undergraduates may consolidate their professional knowledge, better understand and grasp scientific knowledge and method, cultivate their abilities to collect literature information, analyze problems, solve problem, communicate and exchange, team cooperation, experimental operation and creative thinking, and obtain more systematical scientific practice and research training.

\subsection{Pay attention to cultivating undergraduates' information morality in each teaching link}

Modern information technology, particularly network, includes a great deal of information and thus the amount of information undergraduates obtain on campus increases rapidly. But, there is often both right and wrong information, and undergraduates usually cannot make correct judgment, evaluation and choice when they contact the information, leading that students cannot communicate with the outside effectively. If not guide correctly and in time, it often makes undergraduates lost themselves in the sea of information. Therefore, in the process of the integration of information technology and professional teaching, the contents of human education must be penetrated and the cultivation of undergraduates' in science and engineering information literacy strengthened. That is, to implement moral education of undergraduates combined information technology and improve their information awareness, information emotion and information ethnic and morality make them obey the rule of ethnic and morality of information application, not engage in immoral and illegal activities, know how to prevent computer virus and other network criminal activities and effectively resist the erosion of vice information.

In teaching process, the following specific measures may be taken to carry out information morality education. Firstly, in daily teaching, attach importance to the function of moral education of higher education. Make use of the materials of science history to carry out moral education. Make use of scientists' good quality to nurture students and exercise imperceptible and gradual influence on students' moral education. Secondly, attach importance to the role of emotional factors and strengthen communication and exchange with students. For example, create friendly and healthy websites of teachers; carry out common guidance and communication with students by emai, BBS, chat room, and evaluate and give feedback about students' comprehensive performances. Thirdly, Make use of information technology to relate professional learning with society and life fully, demonstrate the charm of science, stimulate students' emotion that they are pleased to do research, love science and pursue truth. Finally, strengthen internet psychological health education. Teachers should guide undergraduates to understand the differences between virtual world and real world correctly, correctly deal with the interpersonal relationship between two world, and pay attention to their internal world and emotional world in order that undergraduates have perfect characters developed harmoniously in real society and online world.

\section{Conclusions}

Information literacy is the basis of lifelong learning and the key for undergraduates to become independent learners in learning society. Because the majors of science and engineering has high requirements about 
information literacy, information literacy has more important role for students majoring in science and engineering. Information literacy can not only help college students effectively identify, evaluate, review and use information from diversified information resources in their learning process, but also help colleges students apply information to solve problems creatively.

Information literacy education of majors of science and engineering in colleges and universities make their students not only grasp how to use liberary resources or have abilities to effectively use diversitified information resources, but also review and use information in the eyes of critical thinking and analized thinking (A. Kasowitz-Schee, M. Pasqualoni, 2002).

The application of information technology in education and teaching provides good educational environment and powerful learning tools for college students' professional learning and development. The organic integration of information technology and professional courses is one of effective paths to develop college students' information literacy majoring in science and engineering. Internet-based quality curriculum enrich and broaden the horizons of classroom teaching of majors in science and engineering, make colleges students understand the status of the development of technology and is conductive to the expansion of students' scientific knowledge.

To open literature retrieval class combined with professional courses can make college students grasp fundamental theory of literature information retrieval and basic technology of information retrieval, know literature information resources related to their majors well and consolidate their professional knowledge.

Research projects may carry out comprehensive scientific and practical training for college students in science and engineering and promote their all-round improvement of information literacy. In each link, directive imperceptible and gradual influence on students' information moral education may be implemented and make college students obtain, use and spread information legally.

This kind of infiltration education of information literacy of science and engineering in colleges and universities not only make students consolidate their professional knowledge, but cultivate their information ability and promote the development of information literacy.

\section{References}

A. Kasowitz-Schee, M. Pasqualoni, Information literacy instruction in higher education: trends and issues, ERIC Digest, Syracuse, NY: ERIC Clearinghouse on Information and Technology, 2002, ED 465375.

Abdelaziz Abid, Information literacy for lifelong learning, http://www.ifla.org/IV/ifla70/papers/116e-Abid.pdf, retrieved July, 2008.

ACRL, Information literacy competency standards for higher education, http://www.ala.org/ ala/acrl/acrlstandards/ information literacy competency.htm, retrieved July, 2008.

ACRL, Information literacy standards for science and engineering/ technology, http://www.ala.org/ala/mgrps/divs/ acrl/standards/ infoliscitech.cfm, retrieved July, 2008.

I.A. Mokhtar, S. Majid, Teaching information literacy for in-depth knowledge and sustained learning, Education for Information, 2006(24): 31-49.

IFLA, Beacons of the Information Society: The Alexandria Proclamation on Information Literacy and Lifelong Learning, http://archive.ifla.org/III/wsis/BeaconInfSoc.html, retrieved July, 2008.

Sun, Haibin. (2007). Reform in the Teaching of Theoretical Mechanics. HIGHER EDUCATION OF SCIENCES. 2007(5): 93-96.

Wang, Fei. (2006). Mode and Approach to cultivate contemporary college students's information literacy. Education Exploration. 2006(5): 37-38.

Yan, Maohua \& Lu, Changmei. (2008). Probe of Innovation Ability Training for College Students in Agricultural Science and Technology Activity. JOURNAL OF ANHUI AGRICULTURAL SCIENCES. 2008(32): 14309-14310.

Yao, Shiyan. (2010). University Student Information Accomplishment Education Connotation Evolution and Way Exploration. JOURNAL OF LIBRARY AND INFORMATION SCIENCES IN AGRICULTURE. 2010(6): 169-171.

Zhao, Jian. (2010). Practices and Thoughts on Information Literacy Education of University Students. JOURNAL OF LIBRARY AND INFORMATION SCIENCES IN AGRICULTURE. 2010(6): 183-186. 